\title{
School environment and practice of accumulated physical activity in young Brazilian students
}

\section{Ambiente escolar e prática de atividade física acumulada em jovens brasileiros escolarizados}

Mona Gizelle Dreger de Oliveira

Raphael Henrique de Oliveira Araújo

Josiene de Oliveira Couto ${ }^{1}$

Antonio Evaldo dos Santos ${ }^{1,2}$

Josivan Rosa Santos $\mathbf{s}^{1,2,3}$

Kenia Rejane de Oliveira Batista ${ }^{1}$

Roberto Jerônimo dos Santos Silva ${ }^{1}$

Abstract - The aim of this study was to verify the association between school environment and accumulated physical activity in Brazilian adolescents. This is a study with secondary data from sample 1 , from the third edition of the National School Health Survey, a study carried out with 102.072 children and adolescents enrolled in the ninth school grade. Questions about characteristics of the school environment and the offer of opportunities for physical activity practices were addressed, focusing on information regarding the structure for physical activity and about the regular practice of accumulated physical activities. Variables were organized from the structure of schools and opportunities for the practice of physical activities, while accumulated physical activity was used as the outcome variable. Data were analyzed from a binary logistic regression model, organized in crude and adjusted models, with a significance level of 5\%. Data were analyzed from SPSS for Windows, version 22.0. Results indicate that, from the adjustment of variables, there was an association between the practice of accumulated physical activity and the existence of a sports court under conditions of use $(\mathrm{OR}=1.22,95 \% \mathrm{CI}=1.18-1.26)$, or presence of courtyard for use of physical education classes $(\mathrm{OR}=1.04,95 \% \mathrm{CI}=1.01-1.06)$. Association between the offer of varied physical activities, except for physical education classes, and the practice of accumulated physical activity $(\mathrm{OR}=1.05,95 \% \mathrm{CI}=1.02-1.08)$ was identified. Existence of a sports court/courtyard in schools and the offer of extracurricular physical activities are associated with the practice of accumulated physical activity in young Brazilian students.

Key words: Exercise; Physical activity; Youth.

Resumo - Objetivou-se verificar a associação entre ambiente escolar e atividade física acumulada em adolescentes brasileiros. Estudo com dados secundários da "Amostra 1" da terceira edição da Pesquisa Nacional de Saúde do Escolar, com 102072 crianças e adolescentes matriculados no nono ano do Ensino Fundamental. Foram abordadas questôes sobre características do ambiente escolar e a oferta de oportunidades de práticas de atividade física, com foco nas informaçôes sobre a estrutura da atividade física e sobre a prática regular de atividades físicas acumuladas. As variáveis foram organizadas a partir da estrutura das escolas e oportunidades para a prática de atividades físicas, enquanto a atividade física acumulada foi utilizada como variável desfecho. Os dados foram analisados a partir de um modelo de regressão logistica binária, organizado em modelos brutos e ajustados, com nivel de significância de 5\%. Os dados foram analisados no SPSS for Windows, versão 22.0. Os resultados indicam que, a partir do ajuste das variáveis, houve associação entre a prática de atividade física acumulada e a existência de quadra poliesportiva sob condiçôes de uso $(O R=1,22 ; I C 95 \%=1,18-1,26)$, ou presença de pátio para uso de aulas de educação física $(O R=1,04 ;$ IC95\%=1,01-1,06). Foi verificada associação entre a oferta de atividades físicas variadas, exceto as aulas de educação física, e a prática de atividade física acumulada $(O R=1,05 ; I C 95 \%=1,02-1,08)$. A existência de quadra de esportes/pátio nas escolas e a oferta de atividades físicas extracurriculares estão associadas à prática de atividade física acumulada em jovens estudantes brasileiros.

Palavras-chave: Adolescente; Atividade física; Exercício.
1 Federal University of Sergipe. Postgraduate Program in Physical Education. Research Center on Physical Fitness, Health, and Performance of Sergipe. São Cristovão, SE. Brazil.

2 Department of Education of Sergipe. Aracaju, SE. Brazil.

3 Estácio University. Aracaju, SE. Brazil

Received: April 27, 2018 Accepted: July 12, 2018 


\section{INTRODUCTION}

Several studies ${ }^{1-3}$ and official documents ${ }^{4,5}$ have pointed to the high prevalence of low levels of physical activity in children and adolescents, especially surveys with the school space as a reference.

The $\mathrm{WHO}^{4}$ recommends that children and adolescents accumulate at least 60 minutes in physical activity practices of moderate intensity daily as a way of promoting health and preventing diseases and adopting an active behavior ${ }^{4,6}$. However, according to the latest PeNSE data ${ }^{5}$, physical activity among Brazilian adolescents is estimated in only $34.4 \%$, which indicates the need for scenarios that favor the adoption of habits for the regular practice of physical activity in and out of school.

Since the school is the place where adolescents spend a great deal of time, it ends up by indicated as the ideal setting for students become physically active $e^{2,3}$. In addition, there is sufficient evidence that the implementation of multi-component physical activity programs increases the level of physical activity of young people ${ }^{7}$.

Similar studies ${ }^{8,9}$ have also pointed to the importance of the school environment as the place where some behaviors, in children and adolescents, can be learned, especially due to the daily time that these individuals spend in this space. Among these behaviors, those directly related to the adoption of habits that lead to the regular practice of physical activities stand out, highlighting some interventions focused on the active commuting to school, the presence of physical education classes, practice, and participation in school competitions and games, recreation activities, among others ${ }^{10,11}$.

In this sense, it is important to identify the factors present in the school environment capable of influencing the practice of physical activity by children and adolescents, considering that participation in school physical education classes is associated with post-school environment health indicators and later in adulthood ${ }^{12}$. These factors, according to Dobbins et al. ${ }^{13}$, should be focused on physiological and psychological elements, sociocultural influence and ecological determinants, as well as the time spent with outdoor activities, especially in the first years of adolescence.

Regarding the regular practice of physical activities, sports and physical exercises, in the school space, studies have pointed out that in addition to the benefits directly related to cardiovascular diseases, there are a number of cognitive benefits directly related to the improvement of academic and behavioral performance, which further reinforces the importance of the existence of a discipline directly related to the empowerment and practice of physical exercises in the school environment, consequently favoring the adoption of a physically active lifestyle out of the school environment ${ }^{14-17}$.

Based on the above, this study aims to identify and discuss the factors that are present in the school environment that influence or could influence the adoption of habits for the regular practice of physical activities in children and adolescents. 


\section{METHODOLOGICAL PROCEDURES}

This study used secondary data obtained from the third edition of the National School Health Survey (PeNSE), carried out in 2015, with support from the agreement between the Brazilian Institute of Geography and Statistics, Ministry of Health and Ministry of Education ${ }^{5}$.

The 2015 PeNSE investigated through the questionnaire applied to schools a set of issues related to the school environment, ranging from information on available infrastructure for food, physical activity, accessibility, basic sanitation and hygiene to information on the existence of rules and standards of behaviors adopted by schools, health care policies and level of environmental safety. Some of this information was used to allow better school characterization.

PeNSE provided results for two different sample plans, with representative data: the first of students attending the $9^{\text {th }}$ grade of elementary school to compare with data from previous editions $(2009,2012)$, observing the trend of data; and the second, with adolescents regularly enrolled in schools aged 13-17 years, compared with indicators developed by the WHO Global School-Based Student Health Survey (GSHS). The national PeNSE sampling strategies and the psychometric properties of the questionnaire were described in detail in documents provided by IBGE.

For this study, data referring to the sampling plan of sample 1 of the 2015 PeNSE, carried out with $9^{\text {th }}$ grade students (morning, afternoon and evening) from the public and private schools of the country were used in the reference year of the survey. This sample was chosen because it contains, in addition to information regarding the students' questionnaires, information regarding the schools questionnaire, fulfilling the aims of the present study.

IBGE has developed a three-stage conglomerate sampling procedure. The sample size was calculated to estimate the parameters of interest in each of the five Major Regions of the Country. In each stratum, the sample size considered a maximum sampling error of approximately $3 \%$, in absolute values, to estimate a proportion of the order of $50 \%$, with a confidence interval of $95 \%$ and average effect of the sampling plan in the first stage.

The research was carried out in 675 municipalities, 3.160 schools and 4.159 classes, of which 102.301 students answered the survey questionnaire and 102.072 were analyzed. Information was collected using a self-administered structured questionnaire, using the Personal Digital Assistant, which allowed students to respond electronically, without interference from the interviewer. All students were asked to complete the questionnaire.

Issues about the characteristics of the school environment and its surroundings were addressed, focusing on information regarding the structure available for physical activity; and on the regular practice of physical activities and physical exercises. It is worth mentioning that PeNSE covers other topics relevant to the monitoring of several risk factors and health protection of the Brazilian adolescent population, which are beyond the scope of this study.

The "accumulated physical activity" indicator, as classified in the 
instrument adopted by the IBGE, was obtained by summing the times spent in three domains referring to the weekly level of physical activity of ninth grade students, as follows: a) The first refers to the commuting from home to school and from school to home; b) the second domain was on physical education classes in school, and; c) the third was about other extracurricular physical activities.

The outcome variable, "accumulated physical activity", was considered for the binary logistic regression analysis, both in the crude and adjusted and quantified analysis from criteria adopted by IBGE, with the sum of values obtained in the "leisure physical activity", "commuting" and "school physical education" domains. Thus, the three domains were not used separately to verify any association.

The Box 1 presents the variables and proper characterizations and categorizations used in this survey, favoring its understanding. For the statistical treatment of this work, SPSS version 22 for Windows ${ }^{\mathrm{TM}}$ was used in all procedures. The PeNSE 2015 was approved by the National Commission for Ethics in Research from the National Health Council, through protocol No. 1.006.467, dated 03/30/2015.

Box 1. Presentation and characterization of variables considered in the study from the National School Health Survey (PeNSE 2015)

\begin{tabular}{|c|c|c|}
\hline Variable & Characterization & Categorization \\
\hline \multirow[t]{5}{*}{ Administrative sphere } & \multirow{5}{*}{$\begin{array}{l}\text { The administrative sphere that charac- } \\
\text { terizes the school unit involved. }\end{array}$} & Municipal \\
\hline & & State \\
\hline & & Municipal \\
\hline & & Federal \\
\hline & & Private \\
\hline \multirow[t]{2}{*}{ The existence of sports court } & \multirow{2}{*}{$\begin{array}{l}\text { "Do not have" and "Not in use", clas- } \\
\text { sified as "No". Answer "Yes" remained } \\
\text { classified as "Yes". Question E01P15a }\end{array}$} & Yes \\
\hline & & No \\
\hline \multirow{2}{*}{$\begin{array}{l}\text { The existence of courtyard } \\
\text { for the practice of physical } \\
\text { activities }\end{array}$} & \multirow{2}{*}{$\begin{array}{l}\text { Answer "Do not have" and "Not used } \\
\text { for practice", classified as "No". Answer } \\
\text { "Yes" remained classified as "Yes". } \\
\text { Question E01P19. }\end{array}$} & Yes \\
\hline & & No \\
\hline \multirow{2}{*}{$\begin{array}{l}\text { The opening of School on week- } \\
\text { ends for the community }\end{array}$} & \multirow{2}{*}{$\begin{array}{l}\text { Considered the answer to the question- } \\
\text { naire referring to question E01P34. }\end{array}$} & Yes \\
\hline & & No \\
\hline \multirow{2}{*}{$\begin{array}{l}\text { Are there activities agreed with } \\
\text { the community on weekends? }\end{array}$} & \multirow{2}{*}{$\begin{array}{l}\text { Considered the response of the ques- } \\
\text { tionnaire referring to question E01P35. }\end{array}$} & Yes \\
\hline & & No \\
\hline \multirow{2}{*}{$\begin{array}{l}\text { The offer of Physical Activi- } \\
\text { ties (except physical education } \\
\text { classes) }\end{array}$} & \multirow{2}{*}{$\begin{array}{l}\text { Answer "No", remained classified as } \\
\text { "No". Other answers, classified as } \\
\text { "Yes". Question E01P22 }\end{array}$} & Yes \\
\hline & & No \\
\hline \multirow{2}{*}{$\begin{array}{l}\text { Participates in Interschool } \\
\text { Games }\end{array}$} & \multirow{2}{*}{$\begin{array}{l}\text { Considered the answer regarding ques- } \\
\text { tion E01P38 }\end{array}$} & Yes \\
\hline & & No \\
\hline \multirow[t]{2}{*}{ Performance of internal games } & \multirow{2}{*}{$\begin{array}{l}\text { Considered the answer of the question- } \\
\text { naire referring to question E01P39 }\end{array}$} & Yes \\
\hline & & No \\
\hline \multirow[b]{2}{*}{ Accumulated Physical Activity } & \multirow[b]{2}{*}{$\begin{array}{c}\text { Quantified from the sum of three } \\
\text { domains: commuting from home to } \\
\text { school, physical education classes, and } \\
\text { other physical activities. "300 minutes } \\
\text { of weekly physical activity" was adopted } \\
\text { as a cutoff point to classify adolescents } \\
\text { as "active" }\end{array}$} & Active \\
\hline & & $\begin{array}{l}\text { Insufficiently } \\
\text { active }\end{array}$ \\
\hline
\end{tabular}




\section{RESULTS}

Of the 102.072 schools responding to the PeNSE questionnaire, 93.789 (91.9\%) were in the urban area, $81.154(79.5 \%)$ had the public sector as administrative dependence (public institutions), of which the administrative sphere was divided as follows: 288 in the Municipal sphere, 49.462 in the State sphere and 31.404 in the Federal sphere.

Table 1. Presentation of variables considered in the Study (PeNSE, 2015).

\begin{tabular}{|c|c|c|c|}
\hline Variables & $n$ & $\%$ & $95 \% \mathrm{Cl}$ \\
\hline \multicolumn{4}{|l|}{ Administrative Sphere } \\
\hline Municipal & 288 & 0.3 & \\
\hline State & 49.462 & 48.5 & $0.20-0.21$ \\
\hline Federal & 31.404 & 30.8 & \\
\hline Private & 20.918 & 20.5 & \\
\hline \multicolumn{4}{|c|}{ Infrastructure for Practice } \\
\hline \multicolumn{4}{|l|}{ Sports Court } \\
\hline Yes & 71.089 & 69.7 & $0.30-0.31$ \\
\hline No & 30.842 & 30.3 & \\
\hline \multicolumn{4}{|l|}{ Courtyard used for PA } \\
\hline Yes & 51.987 & 51.1 & $0.48-0.49$ \\
\hline No & 49.823 & 48.9 & \\
\hline \multicolumn{4}{|l|}{ Sports Equipment } \\
\hline Yes & 91.975 & 90.2 & $0.09-0.10$ \\
\hline No & 9.956 & 9.8 & \\
\hline \multicolumn{4}{|c|}{ School Opens at Weekends for Community } \\
\hline Yes & 40.782 & 40.0 & \\
\hline No & 61.149 & 60.0 & $0.39-0.40$ \\
\hline \multicolumn{4}{|c|}{ Of those who open, activities agreed with the community } \\
\hline Yes & 37.865 & 92.8 & \\
\hline No & 2.917 & 7.2 & $0.92-0.93$ \\
\hline \multicolumn{4}{|c|}{ Physical Activity outside Physical Education classes } \\
\hline \multicolumn{4}{|c|}{ The offer of Physical Activities } \\
\hline Yes & 60.407 & 59.3 & $0.40-0.41$ \\
\hline No & 41.524 & 40.7 & \\
\hline \multicolumn{4}{|l|}{ Interschool Games } \\
\hline Yes & 80.510 & 79.0 & \\
\hline No & 21.421 & 21.0 & $0.78-0.79$ \\
\hline \multicolumn{4}{|l|}{ Internal Games } \\
\hline Yes & 93.238 & 91.5 & \\
\hline No & 8.693 & 8.5 & $0.91-0.92$ \\
\hline \multicolumn{4}{|c|}{ Level of Weekly Physical Activity } \\
\hline \multicolumn{4}{|c|}{ Accumulated Physical Activity } \\
\hline Active & 35.145 & 34.5 & $0.65-0.66$ \\
\hline Insufficiently Active & 66.808 & 65.5 & \\
\hline
\end{tabular}

Note.Cl: Confidence Interval; PA: Physical Activity

Regarding the infrastructure of the 101.931 respondent schools, almost $2 / 3$ reported having sports court suitable for use, and almost half of the 
schools reported that the schoolyard was used for regular physical activity with an instructor or qualified professional, and $90.2 \%$ of schools reported having sports equipment for games under conditions of use. Also, regarding the school infrastructure used for the practice of physical activity, 2/5 of schools reported that it is open on weekends for community use and of these, practically all school units reported that the actions developed in schools during the weekend are agreed with the community.

Of the 101.931 schools that responded to sports activities, which did not include regular Physical Education classes, 59.3\% reported that they offered sports activities to students, $47.7 \%$ of which were offered free of charge, $7.4 \%$ were paid, and $4.2 \%$ offered free and paid activities (data not shown). It is noteworthy that $79 \%$ of schools participated in interschool games and $91.5 \%$ of schools played games among classes, grades or shifts.

Table 1 also shows that approximately $2 / 3$ of students are classified as "insufficiently active", values corroborated by frequencies obtained from students who do not reach recommendations in commuting (93.8\%), physical activities extra school physical education (83\%) and practice of physical education domains (98.5\%) (data not shown).

Table 2. Associations between variables considered in the study and the practice of accumulated physical activity and certain factors of school space in Brazilian adolescents, $n=101.810$ (PeNSE, 2015).

\begin{tabular}{|c|c|c|c|c|}
\hline Variables & CRUDE & $95 \% \mathrm{Cl}$ & ADJUSTED OR & $95 \% \mathrm{Cl}$ \\
\hline \multicolumn{5}{|c|}{ Infrastructure for Practice } \\
\hline \multicolumn{5}{|c|}{ Sports Court } \\
\hline Yes & 1.23 & $1.19-1.26$ & 1.22 & $1.18-1.26$ \\
\hline No & 1 & - & 1 & - \\
\hline \multicolumn{5}{|c|}{ Schoolyard used for PA } \\
\hline Yes & 1.04 & $1.02-1.07$ & 1.04 & $1.01-1.06$ \\
\hline No & 1 & - & 1 & - \\
\hline \multicolumn{5}{|c|}{ Sports Equipment } \\
\hline Yes & 1.11 & $1.06-1.16$ & 1.04 & $0.99-1.08$ \\
\hline No & 1 & - & 1 & - \\
\hline \multicolumn{5}{|c|}{ School opens on Weekends } \\
\hline Yes & 0.99 & $0.97-1.02$ & - & - \\
\hline No & 1 & - & - & - \\
\hline \multicolumn{5}{|c|}{ Physical Activity outside Physical Education classes } \\
\hline \multicolumn{5}{|c|}{ The offer of Physical Activities } \\
\hline Yes & 1.06 & $1.03-1.08$ & 1.05 & $1.02-1.08$ \\
\hline No & 1 & - & 1 & - \\
\hline \multicolumn{5}{|c|}{ Interschool Games } \\
\hline Yes & 1.05 & $1.01-1.08$ & 1.03 & $0.99-1.06$ \\
\hline No & 1 & - & 1 & - \\
\hline \multicolumn{5}{|c|}{ Internal Games } \\
\hline Yes & 1.06 & $1.01-1.11$ & 1.04 & $0.99-1.09$ \\
\hline No & 1 & - & 1 & - \\
\hline
\end{tabular}

Note. Cl: Confidence Interval; OR: Odds Ratio; PA: Physical Activity. 
Table 2 shows the association between level of physical activity of schoolchildren and the infrastructure offered by schools, and it was verified in the gross analysis that the only variable that did not present statistical significance was the fact that the school opens on weekends. But when the adjusted analysis was carried out, it was observed that either the school has a sports court in the use conditions or yard used for the practice of physical activity was associated with the student being more active when compared to schools that did not have a sports court $(\mathrm{OR}=1.22$; IC95\%=1.18-1.26) or courtyard (OR=1.04; 95\%CI=1.01-1.06), respectively.

Regarding the activities offered, excluding Physical Education classes, the association between the offer of varied activities (paid and free) and active students in relation to schools that did not offer physical activities was identified (OR=1.05; 95\%CI=1.02-1.08).

\section{DISCUSSION}

It was observed, as main results, that there are positive associations between accumulated physical activities among Brazilian adolescents and the existence of minimal infrastructure (sports/playgrounds), existence of sports equipment, provision of extracurricular activities to practice physical activities/physical exercises and participation and promotion of school games.

However, when results were adjusted by environmental variables that met the criteria of this study, only the existence of physical space for the practice of physical activities in the school and the offer of extracurricular physical activities were presented as determinants of accumulated physical activity among Brazilian adolescents.

The literature indicates that there is strong evidence supporting physical education in school as a promoter of physical activity in children and adolescents in Latin America ${ }^{18}$; however, by identifying the main factors that may determine the adoption of an active lifestyle according to the school structure, it was verified that the existence of adequate physical space is among the most important.

A study by Mayorga-Vega et al. ${ }^{19}$ using accelerometers in adolescents aged 13-16 years concluded that school physical education contributed about 24.9-32.6\% of the recommended level of physical activity, reinforcing the importance of the school environment for a healthy lifestyle.

The findings of the present study corroborate results obtained in Canada $^{20}$, where adolescents who attended schools with adequate spaces for physical education classes accumulated more time in moderate-vigorous physical activity than students who attended schools without these structures. However, there is a contrast with what was found by Dias et al. ${ }^{21}$, where schoolchildren with regular structures accumulated more steps during school recess than schoolchildren with good structure; however, the focus of the work was related to physical education classes and school recess, not focusing on accumulated physical activities, but indicated that the existence of structure is fundamental for a good response regarding 
the level of physical activity adopted by students.

In a study with Taiwanese children, Lo et al. ${ }^{8}$ also identified that the school structure is associated with better results in health-related physical fitness tests, reinforcing that the space aimed at the practice of physical activities is determinant in the improvement of the physical fitness, when used in activities extra physical education classes, highlighting the concern about levels of physical fitness.

Damázio and Silva ${ }^{22}$ and Lo et al. $^{8}$ reported that having structure such as facilities, teaching materials or physical space, is directly related to favorable results during professional intervention in school, indicating the importance of adequate space for the practice of physical activities, sports court/courtyard to assist in proposals and actions to encourage the regular practice of physical exercises in children and adolescents.

In a study carried out with public schools in the state of Pernambuco aimed at verifying the variation of the school physical structure, Tenório et al. ${ }^{23}$ identified that approximately $3 / 4$ of public high schools have a sports court and $83.1 \%$ have adequate materials for physical education classes, also having identified that most schools organize sports competitions and offer systematized extracurricular physical activities. The authors emphasize that having adequate physical structure and offering extracurricular activities involving physical activities can create a favorable environment for the students participation in diverse activities in school, contributing to the motor development, health, and quality of life. With regard to the benefits of regular physical activity in different age groups, there is evidence that there is a positive association between adopting good habits as a mechanism of primary prevention and improvement of health indicators ${ }^{4,24}$.

Taylor et al. ${ }^{24}$ elaborated a report based on a systematic review that identified the social impact of sports physical activities, levels of physical activity, health, sports performance, violence, culture, and cognition, especially in individuals in the school age. This report points to encouraging results for improvement of health indicators, school performance, especially schools that increased hours of physical-sports activities from two to four or five days a week and that promoted structural improvements and materials for the optimization of results ${ }^{24}$.

In a 21 -year cohort study, Telama et al. ${ }^{25}$ described that habits acquired in childhood and adolescence can be postponed to adulthood, which may contribute to the findings of this study, since an environment favorable to physical activity, as well as routine based on regular physical/sports activities can make young people more active in adult life. The practice of physical activity in the after-school period or in the school recess can significantly contribute to the achievement of the daily physical activity recommendations ${ }^{26-28}$.

In the present study, the provision of extracurricular physical activity was determinant for the practice of physical activity among Brazilian adolescents. In this sense, Thornton et al. ${ }^{28}$ found an association between supervised physical activity in out-of-school activities and physical activ- 
ity accumulations greater than $60 \mathrm{~min} /$ day, except for physical education classes, suggesting the presence of extracurricular activities in the school shift as an important measure for the increased levels of physical activity.

Considering the participation in activities offered in the school shift, an investigation used two forms of activities as a means to promote the practice of physical activities. As a result, it was identified that both game and traditional forms considerably contributed to the accumulation of physical activity and energy expenditures of schoolchildren ${ }^{26}$. This indicates that planned activities, adjacent to the school environment, can be used as a way to provide the accumulation of weekly physical activity, even if performed in the opposite school shift.

In a study with 866 Portuguese adolescents, Pereira et al. ${ }^{29}$ identified that there is a direct association between perceived environment and the regular practice of physical activity in adolescents, indicating that the practice of physical activity in free time or school shift is related to the perceived environment and the presence of structure in the school space.

In addition, other factors such as parental support, the involvement of parents and friends in sports activities, and socioeconomic status may influence the practice of physical activity of adolescents in the school shift $\mathrm{ft}^{27,29,30}$.

As the main positive point to be highlighted in this study, the use of a representative sample of school units throughout the country is highlighted, favoring inferences necessary for this and indicating determinants related to accumulated physical activity among Brazilian adolescents.

\section{CONCLUSION}

Considering a continental extension country, such as Brazil, and in order to better identify determinants by region, it may be interesting to study these determinants by region, facilitating actions in educational and population public policies to increase accumulated physical activity among Brazilian adolescents.

\section{COMPLIANCE WITH ETHICAL STANDARDS}

\section{Funding}

This research did not receive any specific grant from funding agencies in the public, commercial, or not-for-profit sectors. This study was funded by the authors.

\section{Conflict of interest statement}

The authors have no conflict of interests to declare.

\section{Author Contributions}

Conception and definition of the study: MGDO, JOC, KROB, RJSS. Data collection: MGDO, RHOA, JOC, AES. Data analysis: MGDO, RHOA, JOC, AES, JRS, KROB, RJSS. Wrote the paper: MGDO, RHOA, JOC, AES, JRS, KROB, RJSS. 


\section{REFERENCES}

1. Chzhen Y, Moor I, Pickett W, Toczydlowska E, Stevens GWJM. International trends in "bottom-end" inequality in adolescent physical activity and nutrition: HBSC study 2002-2014. Eur J Public Health in press.

2. Solomon MA. Optimizing the Role of Physical Education in Promoting Physical Activity: A Social-Ecological Approach. Res QExerc Sport 2015;86(4):329-37.

3. Silva RJS, Silva DAS, Oliveira AC. Low Physical Activity Levels and Associated Factors in Brazilian Adolescents from Public High Schools. J Phys Act Heal 2014;11(7):1438-45.

4. World Health Organization. Adolescent obesity and related behaviours: trends and inequalities in the WHO European Region, 2002-2014. Genova: World Health Organization 2017:87.

5. Instituto Brasileiro de Geografia e Estatística (IBGE). Instituto Brasileiro de Geografia e Estatística, Pesquisa Nacional de Saúde do Escolar (PeNSE) 2015. IBGE. Rio de Janeiro; 2016:126.

6. World Health Organization. Global Recommendations on Physical Activity for Health. Genova: World Health Organization; 2010:58.

7. Piercy KL, Dorn JM, Fulton JE, Janz KF, Lee SM, McKinnon RA, et al. Opportunities for public health to increase physical activity among youths. Am J Public Health 2015;105(3):421-6.

8. Lo KY, Wu MC, Tung SC, Hsieh CC, Yao HH, Ho CC. Association of School Environment and After-School Physical Activity with Health-Related Physical Fitness among Junior High School Students in Taiwan. Int J Environ Res Public Heal 2017;14(14):83.

9. Bauman AE, Reis RS, Sallis JF, Wells JC, Loos RJ, Martin BW, et al. Correlates of physical activity: why are some people physically active and others not? Lancet 2012;380(9838):258-71.

10. Larouche R, Saunders TJ, John Faulkner GE, Colley R, Tremblay M. Associations between Active School Transport and Physical Activity, Body Composition, and Cardiovascular Fitness: A Systematic Review of 68 Studies. J Phys Act Heal 2014;11(1):206-27.

11. Silva DAS, Chaput J-P, Katzmarzyk PT, Fogelholm M, Hu G, Maher C, et al. Physical Education Classes, Physical Activity, and Sedentary Behavior in Children. Med Sci Sports Exerc 2018;50(5):995-1004.

12. Ekblom-Bak E, Ekblom Ö, Andersson G, Wallin P, Ekblom B. Physical Education and Leisure-Time Physical Activity in Youth Are Both Important for Adulthood Activity, Physical Performance, and Health. J Phys Act Heal 2018;1-10.

13. Dobbins M, DeCorby K, Robeson P, Husson H, Tirilis D. School-based physical activity programs for promoting physical activity and fitness in children and adolescents aged 6-18. Cochrane Database Sys Rev 2013; 28(2):CD007651.

14. Santana CCA, Azevedo LB, Cattuzzo MT, Hill JO, Andrade LP, Prado WL. Physical fitness and academic performance in youth: A systematic review. Scand J Med Sci Sports 2017;27(6):579-603.

15. Donnelly JE, Hillman CH, Castelli D, Etnier JL, Lee S, Tomporowski P, et al. Physical Activity, Fitness, Cognitive Function, and Academic Achievement in Children. Med Sci Sport Exerc 2016;48(6):1197-222.

16. Ardoy DN, Fernández-Rodríguez JM, Jiménez-Pavón D, Castillo R, Ruiz JR, Ortega FB. A Physical Education trial improves adolescents' cognitive performance and academic achievement: the EDUFIT study. Scand J Med Sci Sports 2014;24(1):e52-61.

17. Moore EWG, Fry MD. Physical Education Students' Ownership, Empowerment, and Satisfaction With PE and Physical Activity. Res QExerc Sport 2017;88(4):468-78.

18. Hoehner CM, Soares J, Parra Perez D, Ribeiro IC, Joshu CE, Pratt M, et al. Physical Activity Interventions in Latin America. Am J Prev Med 2008;34(3):224-233.e4. 
19. Mayorga-Vega D, Martínez-Baena A, Viciana J. Does school physical education really contribute to accelerometer-measured daily physical activity and no sedentary behavior in high school students? J Sports Sci 2018;36(17):1913-22.

20. Hobin E, Leatherdale S, Manske S, Dubin J, Elliott S, Veugelers P. A multilevel examination of factors of the school environment and time spent in moderate to vigorous physical activity among a sample of secondary school students in grades 9-12 in Ontario, Canada. Int J Public Health 2012;57(4):699-709.

21. Dias AF, Lemes VB, Brand C, Mello JB, Gaya AR, Gaya ACA, et al. Association between school structure and physical activity in physical education class and school recess. Brazilian J Kinanthropometry Hum Perform 2017;19(2):164.

22. Damazio MS, Paiva Silva MF. O ensino da educação física e o espaço físico em questão. Pensar Prat 2008;11(2):189-96.

23. Tenório MCM, Tassitano RM, Lima MC. Conhecendo o ambiente escolar para as aulas de Educação Física: existe diferença entre as escolas? Rev Bras Ativ Fis Saúde 2012;17(4):307-13.

24. Taylor P, Davies L, Wells P, Gilbertson J, Taylor W. A review of the social impacts of culture and sport. Department for Culture, Media and Sport 2015; Available from: <https://assets.publishing.service.gov.uk/government/uploads/system/uploads/attachment_data/file/416279/A_review_of_the_Social_Impacts_of_Culture_and_Sport.pdf> [2018 jun 21].

25. Telama R, Yang X, Viikari J, Välimäki I, Wanne O, Raitakari O. Physical activity from childhood to adulthood. Am J Prev Med 2005;28(3):267-73.

26. Kahan D, McKenzie TL. Physical Activity and Energy Expenditure During an After-School Running Club: Laps Versus Game Play. J Sch Health 2018;88(3):237-45.

27. Cheung PP. Children's after-school physical activity participation in Hong Kong: Does family socioeconomic status matter? Health Educ J 2017;76(2):221-30.

28. Thornton CM, Cain KL, Conway TL, Kerr J, Saelens BE, Frank LD, et al. Relation of Adolescents' Physical Activity to After-School Recreation Environment. J Phys Act Heal 2017;14(5):382-8.

29. Pereira R, Santos R, Póvoas S, Silva P. Environment perception and leisuretime physical activity in Portuguese high school students. Prev Med Reports 2018;10:221-6.

30. Lau EY, Barr-Anderson DJ, Dowda M, Forthofer M, Saunders RP, Pate RR. Associations between Home Environment and After-School Physical Activity and Sedentary Time among 6th Grade Children. Pediatr Exerc Sci 2015;27(2):226-33.

\section{CORRESPONDING AUTHOR}

Roberto Jerônimo dos Santos Silva Federal University of Sergipe, Departament of Physical Education Marechal Rondon Avenue, Rosa Elze.

São Cristovão/Sergipe - 49100000, Brazil.

E-mail: rjeronimoss@gmail.com 